\title{
It Is Not about the Drugs. A Comparative and Contextual Analysis of Singapore and European Drug Approaches
}

\author{
Rathna N. Koman \\ Pro Bono Centre, School of Law, Singapore Management University, Singapore \\ Email: rathnakoman@smu.edu.sg
}

How to cite this paper: Koman, R. N. (2018). It Is Not about the Drugs. A Comparative and Contextual Analysis of Singapore and European Drug Approaches. Beijing Law Review, 9, 439-459. https://doi.org/10.4236/blr.2018.93027

Received: August 1, 2018

Accepted: September 16, 2018

Published: September 19, 2018

Copyright $\odot 2018$ by author and Scientific Research Publishing Inc. This work is licensed under the Creative Commons Attribution International License (CC BY 4.0).

http://creativecommons.org/licenses/by/4.0/

\section{(c) (i) Open Access}

\begin{abstract}
This article aims to establish that Singapore's drug policy and approach though not in tandem, is consistent with the elements espoused in the harm reduction approach advocated by the Global Commission on drug policies. The Commission takes the position that drug control nationally has to be aligned with the sustainable development goals agenda approved by the member states in 2015. It has recommended abolishing death penalty for all drug related offences, decriminalizing drug possession and cultivation for personal consumption, implementing non-penal sanctions for all low level drug offenders, and exploring non-penal regulatory models following decriminalization. There is a paradigm shift in global attitude towards drug problem. Traditionally, there appears to be two distinct approaches to drug issues: The so-called harm reduction and the harm eradication approach. This paper anchors upon this basic principle of categorization to offer a comparative analysis between the harm reduction approach used in Europe and the harm eradication approach used in Singapore. It argues that Singapore's approach though labelled as one of harm eradication has strong preponderance of the harm reduction elements in rehabilitation, treatment and reintegration of the drug inmates in the Singapore correctional facility. This analysis challenges the traditional classification and provides new ways of making sense of the variances in drug approach given jurisdictional, geographical and cultural nuances. Concomitantly, it recommends having a specialized drug court within the Singapore criminal justice system to augment its harm reduction approach.
\end{abstract}

\section{Keywords}

Harm Reduction Approach, Harm Eradication Approach, Decriminalization, Alternatives to Punishment, Drug Courts, Drug Philosophy 


\section{Introduction}

2019 will sum up the 10 year review of the Global Commission on Drug Policy's 2009 political declaration and plan of action to "counter the world drug problem"1. The Commission takes a health and human rights-centered approach to drug problems which represents a paradigm shift in global attitude towards drug problems (United Nations, 2016).

In 2015, the Commission took the position that drug control nationally has to be aligned with the sustainable development goals agenda approved by the member states (United Nations, 2015). It recommended abolishing death penalty for all drug related offences, decriminalizing drug possession and cultivation for personal consumption, implementing non-penal sanctions for all low-level drug offenders, and exploring non-penal regulatory models following decriminalization. Reflective of the so-called harm reduction approach, it focuses on education, treatment, rehabilitation, aftercare and social integration of drug offenders. Generally, it decriminalizes drug consumption and possession by low level drug offenders. Criminal sanctions may be replaced by administrative consequences, medical treatment and social measures. The focus is placed on increasing resources for treatment, counselling programs and medical interventions for drug addicts. It primarily regards the drug issue as one concerning public health. European jurisdictions appear to espouse this model or variances thereof.

Singapore's approach towards drug problems stands in stark contrast to the Commission's recommended approach. Its approach towards drug offences takes a punitive stand. Singapore's focus is on eradicating supply and demand for drugs. Eradicating supply from the perspective of the courier or trafficker is done by advocating strict laws, sometimes accompanied by death penalty for drug trafficking. Thus far certain compromises have been made in not imposing the death penalty under limited circumstances but the penalty remains. Consequently, decriminalizing drug offences low level or otherwise is out of the equation. Eradicating demand from the perspective of the drug addict on the other hand is done through rehabilitating, treating, counselling and socially integrating him or her back into society. As such, both consumers and suppliers are taken to task punitively for trading and/or consuming drugs regardless of their level of addiction. Given this eradication grounding, this approach is often said to mimic the harm eradication principle. In Singapore, the level of addiction is only a concern when meting out the appropriate rehabilitation in the prison environment for the addicts. Treatment, rehabilitation, counselling, aftercare and attempts to socially integrate reformed addicts are important features of the Singapore model, nonetheless. However, these measures are orchestrated from the prison environment. In sum, Singapore's model appears to demonstrate a strong preponderance towards harm reduction fundamentals in the rehabilitation, treatment and reintegration of illicit drug users.

${ }^{1}$ Hereinafter referred to as the Commission. 
The 10-year global review, inter alia, is meant to improve the implementation of comprehensive, integrated and balanced national drug control strategies and programs that are sustainable. Additionally, it is meant to encourage the sharing of best practices and lessons learnt from dealing with drug issues. However, is it possible to have a consistent approach across the globe towards drug problems given jurisdictional, cultural and geographical nuances? Second, one must be mindful that the traditional categorization takes an absolute stand.

This paper anchors upon this basic principle of categorization to offer a comparative and contextual analysis between the harm reduction approach used in Europe and the harm eradication approach used in Singapore. Can the approach only exist in absolute terms? Is it fundamental that the elements of the harm reduction principles be implemented outside the correctional facility? It is argued that Singapore's approach, though labelled as one of harm eradication, nonetheless has strong preponderance of the harm reduction elements in rehabilitation, treatment and reintegration of the drug inmates in the Singapore correctional facility. Surely the fact that the drug offenders are treated with dignity, counselled, medically treated where necessary and reintegrated into society as useful members must materially count in ascertaining the nature of approach taken towards drug problems. This analysis challenges the traditional classification and provides new ways of making sense of the variances in drug approach given jurisdictional, geographical and cultural nuances. Concomitantly, it recommends having a specialized drug court in the Singapore criminal justice system to augment its harm reduction approach.

\section{Non-Penal Approach to Drug Issues in European Jurisdictions}

\section{1) Basis of the Harm Reduction Approach}

Typically, the European jurisdictions tend to embrace the harm reduction model with variants. This approach in general tends to take a humanitarian, health and human rights centered approach to drug problems with a rehabilitative and preventative focus on drug addiction (EMCDDA, 2015) ${ }^{2}$. The fundamental tenets of this approach require either decriminalization or reduction of penal laws relating to low level drug offences and increasing resources for drug addicts on treatment, counselling and medical interventions (Stevenson, 2011). This approach is not novel. As a matter of fact, this approach has been advocated since 1972, as an alternative or in addition to criminal sanctions as seen in Articles 36(1) (b) and 38(1) of the Single Convention on Narcotic Drugs of 1961 (as amended by the 1972 Protocol on the Single Convention).

Countries subscribing to this approach tend to question the efficacy of the deterrence model of the harm eradication approach (EMCDDA, 2015). Besides the pressure placed on prison state resources and the criminal justice system by the imprisonment of illicit drug offenders, appears to be an important driver for change in approach.

\footnotetext{
${ }^{2}$ This approach would be in contradistinction to the sanctions oriented approach.
} 


\section{2) Reasons Juridical or Otherwise for Changing to Harm Reduction Ap- proach}

There are various reasons for preferring this approach. Proportionality of a sanction to the crime committed has always been a concern for most jurists questioning the sanction oriented approach for drug offences. Proponents of the harm reduction approach take the view that administrative sanctions for low level drug offences, relating to use and consumption, would be a more proportionate response to the criminal wrongdoing as drug addiction is perceived as a social problem in a medical context and not a criminal problem.

Secondly, in the harm reduction approach, treating the addict is regarded as addressing the source of the problem. Successful treatment will enable the reformed individual to integrate and contribute as a useful member of the society. Concomitantly, it will reduce the demand for illicit drugs, given that the criminal drug market thrives on increasing drug dependency, thereby maximizing profits. Given the polar opposite purposes of the illicit drug market and the harm reduction approach, the treatment strategy makes good sense. Next, low level drug consumption and possession or otherwise is seen as a public health problem as it has serious consequences for the addict, the criminal justice system and society at large. If treatment is effective, it will tend to reduce drug related crimes, transmission of diseases and other societal harms (EMCDDA, 2015). Consequently this may reduce recidivism.

Fourth, in jurisdictions where decriminalization is observed, there will be a corollary reduction in utilization of prison resources in the long run. By reducing the structural burdens on the criminal justice system and prison resources, the saved resources can thus be redirected towards treatment, counselling, rehabilitation and medical interventions for addicts (EMCDDA, 2015).

The harm reduction approach is fundamentally human centric and seeks to reduce the social stigma associated with addiction. Besides, by decriminalizing the offence the collateral consequences of criminal sanctions for illegal drug use is removed by avoiding a criminal record and the disabling consequences of such a record ${ }^{3}$. Given these holistic benefits, it is obvious why states are invoking this model. However, to embrace such an approach, there has to first be a paradigm shift in attitude towards drugs, drug offenders and addiction at the societal level.

\section{3) Variants in Treatment of Low Level Drug Offenders}

There are variants in the harm reduction approach. The variants dictate the types of alternative and/or additional measures available for the drug offender during or outside the criminal justice process. Most of the jurisdictions using this model are clear in extending alternative measures only to low level drug offenders, i.e. for cases involving consumption and/or possession of drugs for personal use 4 . In some countries such alternative measures are also offered to

${ }^{3}$ A criminal record tends to mar one's chances of gainful employment given the negative societal perception of engaging former convicts.

${ }^{4}$ This is in contrast to sanction oriented measures which are frequently adopted in harm eradication models. 
low level actors who cultivate, courier and supply drugs for purposes of feeding their drug habit ${ }^{5}$, as they are regarded as a disenfranchised group having embarked on such ventures due to socio-economic marginalization and hence deserving rehabilitation of some sort. This model is consistent with the Commission's 2016 report which advocates a two-step decriminalization (Global Commission on Drug Policy, 2016). The first step advocates decriminalizing low level consumption, possession and/or use, where criminal sanctions would be replaced by administrative consequences, medical treatment and/or social measures. The second step would involve decriminalizing cultivation, couriering and supplying by low level actors for the reasons mentioned earlier (Global Commission on Drug Policy, 2016).

However what constitutes alternative and/or additional measures to legal sanctions varies from country to country. Generally, two main variants can be identified. Under the first variant, some countries decriminalize low level drug consumption and/or possession and accordingly offer direct alternatives to legal sanctions outside the criminal justice system. In this case, community based treatment programs, probation, counselling and/or therapeutic interventions are available as an alternative to legal sanctions (Stevenson, 2011; see also King, 2007). Incidentally this variant has been adopted by several American states (Executive Office of the President of the United States, 2016; Nadelmann \& LaSelle, 2017; The Foundation for AIDS Research, 2014) ${ }^{6}$. As a corollary to these alternatives, drug courts have been set up. These drug courts have the discretion to redirect low level illicit drug users from the traditional criminal justice system

\footnotetext{
${ }^{5}$ This depends on whether soft or hard drugs are involved. In the case of cannabis, there is currently no harmonized law in the European Union addressing it. Administrative or criminal offences with respect to drug offences including cultivation remains the responsibility of individual member states. In Belgium, cultivation of one plant is a minor offence resulting in a fine. In Netherlands, though cultivation of cannabis is not decriminalized, the police has the discretion to confiscate small amounts of cannabis or plants grown for personal use and the owner may avoid prosecution by voluntarily handing the drugs over to the authorities. In Cyprus, cultivation of three or more plants is presumed to be a supply offence. In Denmark, prosecution guidelines consider 100 grams of cannabis plants as the upper limit to be considered for possession for personal use. In the United Kingdom, the 2012 drug offences sentencing guideline proposes the starting point as a fine or community order for the cultivation of nine plants. Portugal, which has been a trailblazer for decriminalizing drug use and personal possession in 2001, cultivation of any amount, even for personal use, still remains a criminal offence. Likewise, Croatia has specifically excluded cultivation or owning one plant for personal use from decriminalization and the offence is punishable with a sentence ranging from six months to 5 years of imprisonment. Cultivation in Finland is also considered a narcotics offence. In Spain, since 2015 cultivation for personal use in places visible to the public is an administrative offence and is punishable by a fine. In Germany, seriously ill patients are allowed to grow, buy and consume their own cannabis under a special license, and medical marijuana is legalised in the Czech Republic. See EMCDDA, 2017; Khalip, 2015. In the United States, currently 23 states allow for private cultivation of cannabis, though the permissible amount varies between states. See Leafly, n.d.

${ }^{6}$ Measures in place in the United States include syringe exchange programs (adopted in 33 states as of 2014) and specialized opioid treatment programs (offered in $9 \%$ of drug treatment facilities as of 2011). Under former President Obama's administration, the integration of substance use services into primary care settings has also been actively promoted through state grants. See Executive Office of the President of the United States, 2016; Nadelmann. \& LaSelle, 2017; Substance Abuse and Mental Health Services Administration, 2011; The Foundation for AIDS Research, 2014.
} 
to drug treatments and community based programs ${ }^{7}$, and where so redirected, a criminal record is avoided (Stevenson, 2011).

Under the second variant, which is endorsed in United Kingdom and some European countries, an alternative to penal sanction is offered as an option when illicit drug offender goes through the criminal justice process for the drug infraction or it may be offered in addition to the traditional criminal sanctions. The alternative options are available at various stages of the criminal justice system from the time of arrest to sentencing in Europe and the United Kingdom. The United Kingdom, Ireland, Malta and Portugal offer alternative non-penal options after arrest (EMCDDA, 2015). Though this is also offered in France, Luxemburg and Romania, the alternative non-penal options are offered only for offences relating to possession and consumption for personal use of illicit drugs. In countries such as Austria, Greece, Latvia and Netherlands, the alternatives are also offered to offenders who have committed other offences which are nonetheless connected to drug usage.

In cases where the alternative options have been accepted, the proceedings, if begun, will be suspended (EMCDDA, 2015). Suspension of proceedings prior to sentence and/or judgment is also possible in many European jurisdictions, where the offenders assume rehabilitative measures or are referred to treatment with consent ${ }^{8}$. The efficacy of the alternatives are premised on the threat of criminal sanctions should the rehabilitative and treatment programs not be undertaken to the satisfaction of the relevant authorities. Under this approach, the alternative options can be offered by the courts ${ }^{9}$, prosecutor or the police. Some European jurisdictions even offer suspension of sentences if the offender successfully undergoes a rehabilitative course ${ }^{10}$.

In brief, the European model seeks to deal primarily with the drug offender and the addiction by offering palatable treatment options at various stages of the

\footnotetext{
${ }^{7}$ As of May 2017, there are more than 3100 drug courts across the United States, half of which are adult treatment drug courts See United States Department of Justice, 2018. See also, Marlowe, D.B., Hardin, C.D., \& Fox, C.L. (2016). Painting the Current Picture: A National Report on Drug Courts and Other Problem-Solving Courts in the United States. National Drug Court Institute. Retrieved from http://www.ndci.org/wp-content/uploads/2016/05/Painting-the-Current-Picture-2016.pdf. ${ }^{8}$ Examples of countries adopting this approach include Austria, Belgium, Czech Republic, Denmark, France, Luxemburg, and Norway. See Suchtmittelgesetz, $\$ 39$ (Austria); Arrêté royal réglementant les substances soporifiques et stupéfiantes, et relatif à la réduction des risques et à l'avis thérapeutique (Belg.); Trestní řád art 307-308 (Czech); Straffleloven \$56-57 (Den); Code de la santé publiqueart. L3423-1 (Fr.); Loi du 19 février 1973 concernant la vente de substances médicamenteuses et la lutte contre la toxicomaniaart. 23 (Lux.); Lov om straff (straffeloven) $\$ 60$ (Nor.). Additionally, in Hungary and Poland, the offender may voluntarily opt for treatment.

${ }^{9}$ Some of these jurisdictions, for instance Norway and Belgium, have specialized drug courts to deal with drug offenders. Drug courts are distinct from regular courts in that they tend to work with other agencies to achieve a comprehensive approach towards drug infractions. However, as a precursor the offender must accept a guilty plea prior to commencing the treatment options offered under the drug courts. The concept of drug courts and its modus operandi will be discussed further in section IV of this paper.

${ }^{10}$ See, e.g., Suchtmittelgesetz $\$ 39$ (Austria); Trestní zákon art 48 (Czech); Reglamento Penitenciario art. 182 (Spain); Gesetz über den Verkehr mit Betäubungsmitteln (Betäubungsmittelgesetz-BtMG) $\$ 35$ (Ger.); Krimināllikums $\$ 55$ (Lat.); sr Art. 14a (Neth.). Specifically, in Austria, since 2008 it is mandatory to suspend the sentences if the prescribed legislative conditions are satisfied.
} 
criminal justice system as an alternative or in addition to the existing judicial options. Ultimately, the focus is on treating the individual and the root cause of the problem.

Norway's drug approach bears special mention here as it appears to take adual approach that straddles between eradication and reduction. Having started with the harm eradication approach in the 1960s, the reduction measures assumed dominance by the 1990s. The 60's Norway drug approach was similar to Singapore's stand on drugs, eradication above all. Laws were punitive and designed to have a deterrent effect (Skretting, 2014; see also Justis-ogpoliti departement et, 1967). The change in attitude from straightforward eradication to the reduction approach stemmed possibly from three realities. First, an acknowledgement that it was just not possible to have a drug free society. Second, the fact that drug overdose fatalities were rising by 1990s in Norway. Third, the deteriorating health of chronic drug abusers which the state recognised its responsibility to ameliorate (Nesvaag \& Lie, 2010). However, one should not be mistaken that Norwegian drug policy is liberal by any sense of the word. The current drug policy approach in Norway appears to assume a middle ground. Some of the harm reduction measures assumed in Norway are large scale distribution of free syringes and needles for drug users, availability of substitution treatments, establishing low threshold health services for substance abuse, provision of injection rooms, empowering drug users, improving follow up after non-fatal doses, improving suicide risk assessment, measures for suicide prevention (Skretting, 2014; see also SIRUS Norwegian Institute for Alcohol and Drug Research, 2014). Similar reduction measures were also provided in the prison environment (Giertsen, 2012). The health of drug addicts assumed significance. Hence a coordinated health and human centric approach is taken between the police, community and the social welfare system for treatment, rehabilitation, medical interventions and counselling (Norwegian Ministry of Health and Care Services, 2009). At the same time, preventative and strict legal measures continue to exist for possession and supply of illicit drugs (Lov om legemidler $\mathrm{m} v \$ 31$; Lov om straff $\$ \$ 231-232)$. Prevention is still an important facet in educating society, particularly the young on the ill effects of drugs.

In addition, Norway has drug courts and like its European counterparts, the courts have the discretion to sentence addicts to drug treatment programs as an alternative measure or in lieu of sentence if attended for a minimum probationary period (Lov om gjennomføring av straff mv. (straffegjennomføring sloven) $\$ 12$ ). These courts are relatively new given that it only became a permanent and a nationwide feature in 2016 after completion of a trial period (SIRUS Norwegian Institute for Alcohol and Drug Research, 2014). In all, Norway's drug approach can be said to be consistent with the Commission's policy.

\section{The Singaporean Drug Approach}

\section{1) Singapore's philosophy on drug control in context}

Singapore's philosophy on drug control, though often sweepingly said to take 
a purely punitive stand, must be understood in context. To achieve a drug free society, Singapore's drug strategies are geared towards preventative drug education, strong enforcement, deterrent and certainty of punishment (Osman, 2002). For drug inmates, treatment, rehabilitation and aftercare coupled with providing skills and opportunities for gainful employment are of primary importance. It entails a two-pronged approach.

This two-pronged approach translates into Singapore's supply and demand reduction drug strategy. Supply reduction is to be achieved by punishing drug trafficking harshly with either the death penalty or life imprisonment coupled with mandatory caning depending on the type and quantity of drug trafficked. On the other hand, demand reduction is to be achieved through rehabilitation, education, vocational training, constant supervision and aftercare monitoring of drug addicts.

Singapore's reasons for taking this stand against drug trafficking is simple. Located geographically around major drug centers and with millions of travellers passing through its borders and with a high purchasing power, Singapore takes the position that it will be "washed over with drugs" if it takes a soft stand against drugs (Shanmugam, 2016). Though an iron fist approach is adopted, rehabilitation, treatment and reintegration nonetheless takes center stage during and post imprisonment of drug offenders.

To understand Singapore's drug approach, one must note that that drug use in Singapore is primarily seen as a moral and not a medical issue. Hence drug addiction/infraction is seen like any other criminal behaviour, warranting penal consequences (Yew, 1999). It is categorized as a social and behavioural deviance warranting a custodial and penal approach, with the addict expected to take responsibility for his or her own choices (Yew, 1999). Nevertheless, the system clearly recognizes the need to treat addiction and the addict rehabilitated notwithstanding the criminal infraction. Thus, the provision of rehabilitative necessities in the penal institution for drug inmates.

2) The laws governing illicit drug use and trafficking

The Misuse of Drugs Act ("MDA") governs illicit drug use and trafficking. The Central Narcotics Bureau ("CNB") is the government department charged with dealing with these drug issues. Under section 8(a) and (b) of the MDA, it is an offence for a person to possess or consume controlled drugs stipulated in the First Schedule. Punishment for unauthorized possession of a controlled drug can result in a maximum prison term of 10 years and/or a $\$ \$ 20,000$ fine (MDA $\$ 8(a)$; Second Schedule). For unauthorized drug consumption, Singapore advocates a mandatory treatment and supervision regime. A CNB officer with the rank of sergeant and above has the power to request a urine or hair specimen from a person suspected of having consumed an unauthorized controlled or specified drug (MDA $₫ 31(1)$; $\$ 31 A(1))^{11}$. Drug addicts can also be detained un-

${ }^{11}$ Failure to provide a specimen of urine and/or hair without reasonable excuse amounts to an offence under $\$ 31(2)$ and $\$ 31 \mathrm{~A}(2) \mathrm{MDA}$ respectively. The Second Schedule provides that the offender can be punished up to a maximum 10 years and/or $\$ \$ 20,000$ and for the latter to a maximum of 2 years and/or S\$5000 for the respective offences. 
der the executive order of the Director of CNB pursuant to section 34 of the MDA. Under section 34 of the MDA, where it appears to the Director of CNB that it is necessary for the person subject of the urine or hair tests to be supervised, treated or rehabilitated, he may also make such order appropriately. A positive drug tests is sufficient for the Director to make a supervision order for a period not exceeding two years or for that person to be confined in a DRC for treatment and rehabilitation for a maximum period of three years from the date of admission (MDA $\$ \$ 34(2)(a)-(b)$ ). For avoidance of doubt, it is irrelevant whether the unauthorized consumption took place within or outside of Singapore territory. As long as the offender is a Singapore citizen or permanent resident, the law stated above, for unauthorized consumption, applies (MDA §8A).

Given Singapore's penal drug philosophy and strategy, it is apparent that Singapore is nowhere close to decriminalizing drug possession and cultivation for personal consumption. As explained earlier, Singapore sees drug offences no different from other criminal infractions, therefore the parity of punishment of offenders takes precedence. Besides, Singapore is a firm advocate of the principle of general deterrence and this is reflected in the punishments meted out for drug offences (Mervin Singh V PP, 2013; Nagaenthran a/L K Dharmalingam V PP, 2011; PP v Tan Kiam Peng, 2007; Suventher Shanmugam v. PP, 2017) ${ }^{12}$. Therefore, the issue of having non-penal sanctions for all low level drug offenders and exploring non-penal regulatory models following decriminalization is a non-starter.

Singapore also recognizes the changing profile of drug abusers and the drugs and substances abused. This is illustrated by the inclusion of methamphetamines in the MDA in 1997 (Misuse of Drugs Act (Amendment of First Schedule) Order, 1997). Further, in the 1980s, the increase in cases of glue sniffing and other volatile substances was addressed by the passing of the Intoxicating Substances Act ("ISA"). Amongst others, the ISA ensures supply eradication of these harmful substances by prohibiting shopkeepers from selling glue and thinners to suspected substance abusers (ISA $\$ 4)^{13}$. Additionally, these shopkeepers are required under the law to maintain a register of customers who had purchased such volatile substances (ISA \$5). The regime available for these offenders is similar in substance to that mentioned above. Likewise, these offenders can be arrested on suspicion of abuse by CNB officers (ISA \$7) and if the tests are affirmative can be subjected to supervision for a period not exceeding 12 months (ISA \$16) or treatment and rehabilitation (ISA \$17).

CNB officers have the power to arrest and detain suspected persons, and to enter and search any place for purposes of arrest and detention under sections 44, 45 and 46 of the Criminal Law (Temporary Provisions) Act ("CLTPA").

\footnotetext{
${ }^{12}$ Deterrence has long been identified as the cornerstone of Singapore's sentencing jurisprudence, and the Singapore courts have recognised that the sentence imposed for drug possession offences should be proportional to the quantity of drugs in question in order to give effect to the policy of the law on drug offences.

${ }^{13}$ Failure to do so is an offence punishable with a fine not exceeding $\$ \$ 5000$ or imprisonment term not exceeding 2 years. See ISA $\$ 4(2)$.
} 
CLTPA allows detention of suspected persons without trial on grounds of public safety, peace and good order. Additionally, under section 30 of the CLTPA, the Minister has the power to detain any person in the interests of public safety, peace and good order if the person is associated with activities of a criminal nature. In 2018, amendments were proposed to the CLTPA, inter alia, prescribing a list of offences that will come under the purview of the Act. This proposed list included drug trafficking as one of the offences to come under the governance of the CLTPA. It was stated that the purpose of having a proposed list of offences was to ensure "more certainty and clarity" (Singapore Parliamentary Report, 2018; see also Tan, 2018). In brief, under the new amended framework, two criteria has to be satisfied before a detention order can be issued: first, the offence committed is within the purview of the CLTPA and second, the Minister is satisfied of the grounds for detention (Singapore Parliamentary Report, 2018). The fact that CLTPA is used in this context clearly shows that Singapore views drug traffickers as a fundamental threat to society.

With regards to laws against drug trafficking, Singapore has one of the most harsh punishment provisions in the world. The laws against drug trafficking without doubt embody the spirit of the harm eradication approach. Section 5(1) of the MDA clearly states that it is an offence to traffic in a controlled drug. Two presumptions of law operate against a trafficker when found in actual or constructive possession of a controlled drug in the requisite quantities stated in section 17 of the $\mathrm{MDA}^{14}$. First, that person is presumed to traffic in that controlled drugs by reason of the possession. Second, by virtue of actual or constructive possession the person is presumed to have knowledge of those drugs ${ }^{15}$.

The punishment for trafficking differs according to the nature of the drugs and quantity trafficked (MDA Second Schedule). The maximum punishment of death penalty is given when the drug trafficked is opium, morphine, diamorphine, cocaine, cannabis, cannabis mixture, and methamphetamine if it exceeds a certain stipulated quantity. Likewise, the death penalty is given when these aforementioned controlled drugs are manufactured. The death penalty also prevails for import or export of these drugs if the quantities stipulated in MDA are met or exceeded.

The court however is given a discretion to not impose the death penalty under two very limited circumstances, pursuant to section 33B of the MDA. In cases where the exceptions apply, the court has the discretion to impose life imprisonment and canning of not less than 15 strokes of the cane, instead of the death penalty (MDA $₫ 33 \mathrm{~B}(1)$ (a)). Otherwise the death penalty applies.

The first exception applies when the Public Prosecutor certifies that the traf-

\footnotetext{
${ }^{14}$ See the Second Schedule to the MDA which lists the various controlled drugs and the respective stipulated quantities to constitute trafficking within the meaning of the MDA.

${ }^{15}$ Constructive possession will include situations where the offender has (a) anything containing a controlled drug; (b) keys of anything containing a controlled drug; (c) keys of any place or premises or any part thereof in which a controlled drug is found; (d) a document of title relating to the controlled drug or any other document intended for the delivery of the controlled drug. See MDA $\$ 18(1), \$ 18(2)$.
} 
ficker has substantively assisted the CNB in disrupting drug trafficking activities (MDA §33B (2) (b)). However, it is pertinent to note that the Public Prosecutor has the sole discretion in deciding whether a substantive assistance certificate is to be issued to a trafficker (MDA $₫ 33 \mathrm{~B}(4)$ ). This exception to the death penalty recognizes that at times the trafficker is only a drug mule but may nonetheless be able to render useful assistance in investigations relating to wider drug cartel operations and king-pins. This is consistent with Singapore's holistic approach to achieving a drug free society.

The second exception to death penalty exists when the offender proves on a balance of probabilities that he was suffering from such an abnormality of mind (arising from a condition of arrested or retarded development of mind or any inherent causes or induced by disease or injury) that substantially impaired his mental responsibility for his acts or omissions in relation to the offence (MDA $\S 33 \mathrm{~B}(b))$. Often termed as the diminished responsibility defense, it was previously only available as a special defense to murder. However, following amendments to the MDA in 2012, this diminished responsibility defense became available to drug traffickers under section 33B(3) (b) (Misuse of Drugs (Amendment) Act 2012; see also Singapore Parliamentary Report, 2012).

Other than not abolishing death penalty, the abovementioned approach towards drug traffickers is arguably not inconsistent with the global drug approach or the Commission's recommended approach. The Commission's approach deals with low level drug offences which does not include drug possession for the purpose of trafficking. Moreover, though Singapore has not abolished its death penalty provision, it must be noted that it has dialled down on its imposition of the death penalty for traffickers under the two aforementioned exceptions. It must be recognized that concessions have been made to an extent that is palatable to the Singapore's drug policy.

\section{3) Drug Rehabilitation Centers ("DRCs") for drug inmates}

With respect to addicts, the correctional facility has an elaborate system for rehabilitation. Drug inmates are institutionalized in DRCs. A correctional facility of the Changi Prison Complex, it comes under the purview of the prison system, funded by state resources. The detention at DRC is primarily a social control, to serve the punishment and to rehabilitate. Through rehabilitation, the system seeks to manage inmates, reduce reoffending and facilitate reintegration into society (Yew, 1999) ${ }^{16}$.

At the DRC, addicts are segregated into hard-core and non-hard-core addicts $^{17}$ which will dictate the duration, type of treatment and rehabilitation received (Central Narcotics Bureau, n.d.). The inmates' progress are reviewed every six months by the DRC Review Committee, which is chaired by a medical

\footnotetext{
${ }^{16}$ Given the goals of the DRCs, the detention is categorized into four periods: (1) detox; (2) recuperation and transfer; (3) physical fitness; and (4) rehabilitation.

${ }^{17}$ Under Singapore's drug regime, first and second time offenders are categorized as non-hardcore addicts, whereas the classification of hardcore addicts are utilized for offenders who offended three times and above. See Yew, 1999.
} 
practitioner (Yew, 1999). Though Singapore does not view drug addiction as a medical problem, the fact that the Review Committee is chaired by a medical practitioner clearly recognises the importance of medical science in treatment, care and rehabilitation of drug inmates.

Segregation also seeks to prevent the spread of the drug problem internally by reducing negative social modelling and sub-culture within ${ }^{18}$. Therefore, hard-core addicts face a longer duration in the DRC and are subjected to a tough penal-like regime with minimal privileges and enhanced measures of deterrence. Since 2013, hard-core drug offenders with higher risk of re-offending will spend their last 10 months at the Pre-Release Center ("PRC") at the Changi Prison Complex as part of the efforts to empower them to break their chain of re-offending and to normalize them to reintegrate into society. During these 10 months, the inmates go through therapeutic interventions, confidence buildings sessions, experiential learning, learn employability skills under programs initiated by the Singapore Corporation of Rehabilitative Enterprises ("SCORE") in tandem with counselling sessions to assist inmates to break through their criminal mind-sets and realize their self-worth (Jalelah, 2013; see also Singapore Prison Service, n.d.).

Non-hard-core offenders on the other hand are given opportunities to enrol in educational or vocational courses with inbuilt intensive counselling and enhanced rehabilitative measures. They are seen as having a greater potential to reform, rehabilitate and reintegrate into society, given the lesser infractions with drugs.

The rehabilitation treatment consists of specific drug treatment programs. Upon completion of the minimum detention period in the DRC, the offender may opt to undergo community based rehabilitation ("CBR") or extended institutional rehabilitation ("EIR"). Where CBR is chosen, he or she will be kept in detention for another 12 to 24 months. During this period of detention the addict continues with the rehabilitation program and additionally undertakes vocational training and work. The inmate will also receive counselling during this period. Under CBR, if the offender has adequate family support, he can opt for the residential scheme where the individual will be electronically tagged, monitored and allowed to return home after work. Otherwise, the offender can join the halfway house scheme, which is targeted for inmates who express desire for reform but lack the necessary family support. In these cases the halfway house acts as the crutch ${ }^{19}$ and the social support provided by the halfway house via counselling, discipline, regular urine testing, and the work during the day aims to successfully reintegrate them into the society (Yew, 1999; see also Singapore Prison Service, n.d.). Nevertheless, at all times during CBR or otherwise, the in${ }^{18}$ This ensures that hardcore addicts do not further cultivate negative drug habits amongst non-hardcore offenders. See Yew, 1999.

${ }^{19}$ At present, the halfway houses are run by voluntary welfare organizations, though a new government halfway house for ex-offenders is slated to be ready by 2018. See "New govt-run halfway house for ex-offenders to be ready by 2018", 2014; see also Singapore Corporation of Rehabilitative Enterprises, n.d. 
mates remain within the jurisdictional control of the Prison Department. The main aim of CBR is to reintegrate treated addicts into society.

It is important to note that the general rehabilitation program in the prison environment consists of five elements. First, inculcation of discipline via soft skills training for a job. To this end, SCORE, a statutory board plays a significant role in the Singapore correctional system. Established in 1976, it offers rehabilitative and aftercare services to inmates and ex-offenders. These services focus on training, work, employment assistance and community engagement, enhancing the employment prospects of inmates and ex-offenders so that they can functionally reintegrate into the national workforce ${ }^{20}$.

Second, providing education to upgrade inmates' educational status, academically or vocationally. This is because low education is typically seen as a "predictor of offending" in an educationally competitive country like Singapore (Yew, 1999). Third, physical training to relief the rigors of imprisonment and to keep inmates healthy. Fourth, religious counselling is also offered to provide for the spiritual needs of the inmate. Fifth, counselling is provided by a team of specialist counsellors to the inmate and the family members where necessary (Yew, 1999). The system makes a concerted effort to ensure that during the process of rehabilitation, the inmates remain focused and not distracted by stress triggers, personal or otherwise ${ }^{21}$.

The fact that all of the above is orchestrated from the prison environment and that different stakeholders have come together to ensure that the addicts not only rehabilitate but are functionally reintegrated into society is commendable. The fact that addicts are placed in gainful employment, counselled ${ }^{22}$, treated for their addiction either via substitution treatment or otherwise, monitored post release and/or placed in halfway houses for support demonstrates the strong commitment taken by the government and the various stakeholders towards sustainable goals. A multi-faceted model is utilized, one based on the economics of work, changing mind-sets, regular counselling, religious or otherwise, provision of medical treatment opportunities or programs (Peh \& Ng, 2006; see also Chan, 1996) and most importantly, the invoking of familial and community support.

Singapore's correctional institute has a well thought structure of treatment and rehabilitation program for drug addicts. Though often stated to purely adopt a harm eradication approach towards drugs, a closer look at the measures taken to reduce demand for drugs demonstrates principal elements of the harm reduction model. This appears to be the situation even for the high risk offenders. Though Singapore does not adopt non-penal regulatory sanctions for the low level drug offenders, it is indisputable that the correctional institute's system and plan for drug inmates is human and health centered given the structured ${ }^{20}$ See generally SCORE Website, https://www.score.gov.sg.

${ }^{21}$ This is consistent with the mission statement of the Singapore Prison Service, which is to ensure safe custody of offenders and to provide opportunities for rehabilitation. for inmates who are deserving and capable of rehabilitation. See Singapore Prison Service, n.d.

${ }^{22}$ Counselling is not only extended to the inmate but also to the family members as drug issues are regarded as requiring a holistic approach to tackle. 
manner in which the drug inmates are treated, rehabilitated and counselled. Coupled with SCORE, the effort to reintegrate the offenders into the society demonstrates Singapore's strong commitment to rehabilitate and reintegrate the drug offenders into society and achieve sustainable goals. Seen from this perspective, Singapore's approach is arguably consistent with Articles 36(1) (b) and 38(1) of the 1961 Single Convention on Narcotic Drugs which requires the Member States to take all practicable measures for the prevention of abuse of drugs and for the early identification, treatment, education, after-care, rehabilitation and social reintegration of drug offenders.

Given the above, is it juristically important that the harm reduction elements of treatment, education, aftercare, rehabilitation and social integration of addicts be orchestrated from a non-penal, non-correctional institute or the Ministry of Health? The answer to this simply must be that it is irrelevant which institute is orchestrating the harm reduction elements if the implementation is efficient, effective, sustainable, human and health centered. It must be noted that Norway which now focuses on a dual approach has not forgone its preventative approach towards drugs. Besides, it was also not always the case in Singapore that the DRC was housed under the penal institute. A perusal of Singapore's history will reveal that in the 1960s, the drug treatment center was administered by the Ministry of Health as it was then acknowledged that drug addiction was a social problem in a medical context and not a criminal problem. However, due to the alarming increase in cases of drug abuse, the need to deter such abuse took precedence, thereby giving rise to the system as it is today (Yew, 1999). Notwithstanding this shift, a close nexus exists between the penal institute and the Ministry of Health as evidenced by the treatment and rehabilitative options available for the addicts (EMCDDA, 2015).

Notwithstanding the above, enhancements can be made to the existing drug approach taken in Singapore. For instance, it remains that to this day we do not have drug courts or commissions to deal with drug offenders. Drug courts are instrumental in augmenting harm reduction fundamentals.

\section{Creating Drug Courts to Enhance Harm Reduction Fundamentals}

Drug courts are not new to the world. They are a common feature in some parts of the Europe, United Kingdom, and United States. Drug courts generally operate within the existing legislation and have powers similar to regular courts. However, three specific features of these courts must be noted.

First, it is specialized in dealing only with drug offenders. Second, the judge plays an important role in the ongoing review of the drug offenders' progress. The judge may be legally or medically trained. In some countries, the supervising panel is not legally trained given the medical nuances of the treatment involved. On the other hand, in some European jurisdictions, the criminal law judge partners with a team of correctional, health and welfare professionals (EMCDDA, 2015). Third, drug courts fill an important gap in the range of 
community based measures and sanctions available to the drug user so as to be able to deal specifically with the nuances of the drug offence, offender and/or the drug related crime.

Drug courts may be categorized according to the type of offenders they deal with. In the United States, there are typically two types of drug courts, one for adult offenders and another for juvenile offenders. The court is responsible for granting the appropriate community based measures and sanctions to the offender and monitoring and reviewing the ongoing progress. During the period of review, the offenders receive access to drug treatment and any other necessary types of support. To assess compliance, drug offenders are tested regularly and progress reports are submitted to the court. The presiding judge has the power to vary the requirements of the order based on the review.

The purpose of the drug courts is to combine drug treatment with the legal and moral authority of the court so as to reduce the rate of recidivism (Mitchell, Wilson, Eggers \& MacKenzie, 2012). The process is outcome driven. Though some meta-analysis in the United States has suggested that drug courts do contribute to reductions in drug use, drug related crimes and improvements of overall well-being of the offender, it is unclear for how long and which specific features of the drug courts actually contribute to reducing the rate of recidivism (Mitchell et al., 2012). The analysis has also suggested that adult drug courts dealing with non-violent drug offenders are more effective in reducing recidivism (Mitchell et al., 2012). Given that drug courts are structured to give ongoing targeted, streamlined and customized treatment options for the drug offender, there is continuity in dealing with the drug offender and his or her progress.

The modus operandi of a drug courts differs between jurisdictions. In the United States, it is conducted in a non-adversarial collaborative manner and the drug offender, regarded as a client, can be referred to the drug courts during three stages of the criminal process. The referral can happen after the arrest or pre-plea stage or after conviction but before sentencing. In cases where he or she is referred pre-plea, the offender must waive his right to a regular trial and upon successful completion of the court requirements, the criminal charges would be dropped. In the case of being referred post plea and successful completion of the requirements, the offender receives sentence of time served or probation (Mitchell et al., 2012). Hence entry to drug courts in United States is voluntary. This seems to ensure buy-in by the participant given that the process is a demanding option requiring commitment and cooperation over the period of treatment.

In European jurisdictions, generally the offender has to accept a guilty plea to be within the drug court process. This acts as a threat to ensure continuity of treatment, participation and completion of the treatment (EMCDDA, 2015). In this context, the European drug courts uses the "sanctions and rewards" approach to motivate and ensure cooperation and compliance by participants.

A drug court can be modelled based on the individual needs of the country. Setting up a drug court in Singapore will enhance the harm reduction fundamentals. First, this is conceptually possible given that in the last ten years we 
have moved towards setting up specialized courts dealing with certain issues at the State Court level ${ }^{23}$. Thus, to have a specialized drug court dealing with illicit drug users in our criminal justice system conceptually is not unfathomable or novel.

Second, most of the drug courts in existence tends to offer community based sanctions to the offender, a specialty of these courts. The concept of community based sentences is not new to the Singapore criminal justice system. Singapore has been moving towards a wide range of community based sentences since 2010 for offences in the rehabilitative spectrum (Criminal Procedure Code, $\$ \$ 335-348$; see also Chng, 2011). Hence, it should not be an issue to devise community based sanctions modelled on the European drug courts. This would require an amendment of the existing laws with respect to illicit drug users. Offering community based sentences to offenders of less serious offences is philosophically more justifiable than drug offenders, given that drug infraction is seen as a serious moral issue since the colonial times ${ }^{24}$. Nonetheless, offering community based sanctions in drug courts must be seen in the context of rehabilitation, which if successful will reduce the demand for illicit drugs which is the primary objective of the Singapore drug approach. Should this be offered it may be prudent to offer such community based sentences on a "sanctions and rewards basis" as the European counterparts. This would encourage participation, continuity and completion of treatment by the drug offender. Given the benefits of judicial continuity, customized and streamlined community based treatment options, setting up a drug court at the State Court level in the Singapore criminal justice system to deal with illicit drug users would well augment Singapore's rehabilitative approach to drug problems.

Third, it is important to determine the panel warranted for such a court. Traditionally, the courts in Singapore are presided by legally trained individuals. However given the outcome driven nature of a drug court and the fact that the judge plays a crucial role in the ongoing review of the drug offender's progress, the judge ought to be either medically trained or be partnered with a team of correctional, health and welfare professionals. This is imperative given the medical nuances of the treatment and ongoing review.

Notwithstanding the above, to consider the viability of drug courts in our system, a couple of important issues needs to be considered. First, the issue of funding. Drug courts are resource intensive given the continuous need for customized review. The controversy is whether state funds should be utilized for drug courts given that drugs addiction is seen as a moral issue for which the of-

\footnotetext{
${ }^{23}$ The Community Court was set up in the Singapore State Courts on $1^{\text {st }}$ June 2006. The Community Court deals with special categories of cases, such as those involving young offenders aged 16 to below 21, offenders with mental disabilities, neighbourhood disputes, et cetera. The Community Court is committed to rehabilitating offenders and preventing re-offence, and does so through a multi-disciplinary approach to address the root causes of the offending behaviour. See State Courts Singapore, 2014.

${ }^{24}$ Drug infraction has been classified as a morally irresponsible act committed towards the family and society at large. See Abdullah, 2005.
} 
fender must bear responsibility. This may not be such an issue given that the current system in the correctional facility, is state funded and is also resource intensive in treating and rehabilitating illicit drug users. The issue then is really how much more of the state funds can be extended to this cause.

Next, if setting up a drug court is viable, a review must be done to ascertain how the rehabilitation and treatment program orchestrated at the correctional facility will complement the drug court so as to achieve consistency in drug program implementation, avoid duplication and a corollary wastage of resources to this end.

Third, we need to carefully analyze the eligibility criteria for the drug courts. Ascertaining this eligibility criteria is important for the effective functioning of the drug courts. If the drug courts process is outcome driven, its effectiveness will be judged by the successful reduction of the recidivism rate. In this regard, the meta-analytic research conducted in the United States showed that drug courts that focused on adult non-violent drug offenders were more effective and achieved a greater reduction rate of recidivism as compared to the juvenile drug courts. The latter catered to high risk offenders and had less demanding interventions ${ }^{25}$. Thus it is recommended that a pilot run should first deal with non-violent drug offenders to assess its effectiveness in reducing recidivism. For the same reasons, drug offenders with serious mental afflictions and prior violent convictions for a start should be precluded from availing the drug courts process. Moreover, given Singapore's position on drugs and drug offenders, the palatable option would be to have drug courts only for low level drug possession and consumption offences. Drug supply offences such as trafficking should remain within the purview of the regular criminal justice process. To this end, traffickers who engage in trafficking to support their habit should be availed the drug courts process. It is submitted that such an approach is sustainable and consistent with the Commission's policy on harm reduction fundamentals.

\section{Conclusions}

Global conventions in the last 30 years have echoed rehabilitative and treatment measures as an alternative or in addition to the traditional sanctions. Nonetheless, drug trafficking and sale is still illegal in most countries. A perusal of the World Convention on Drugs will reveal that the world initially took a punitive approach. Singapore has retained the punitive approach towards drug trafficking and stands firmly by it. However, Singapore does not refute the health and human centered approach to illicit drug users but rather disagrees with the manner in which such fundamentals are to be orchestrated for these individuals. Its correctional facility demonstrates a strong commitment to harm reduction fundamentals. Treatment, counselling, rehabilitation and reintegration programs for

${ }^{25}$ In the juvenile drug courts, testing conditions and status hearings are reduced, while the programs are also of a shorter duration. See Mitchell et al., 2012. See also Blair, L., Sullivan, C., Latessa, E., \& Sullivan, C.J. (2015). Juvenile drug courts: A process, outcome, and impact evaluation. Office of Juvenile Justice and Delinquency Prevention. Retrieved from https://www.ojjdp.gov/pubs/248406.pdf. 
an addict remains a core feature of the correctional institute. Setting up a drug court in the Singapore criminal justice system would justifiably add value to rehabilitation and harm reduction fundamentals. Though syringe and needle exchange programs, drug injections rooms, et cetera will never see the day in the Singapore drug system, the fact remains that a lot of attention and resources has been dedicated to the needs of the illicit drug users which positively impacts three levels of the society: the drug offender, the criminal justice system and society at large.

In sum, the goals of the countries in tackling drug issues are indeed aligned, however the manner in achieving these goals sustainably will remain distinct and individual given the jurisdictional, geographical and cultural nuances.

\section{Acknowledgements}

The author would like to thank her research assistant Melina Chew for her research and editorial assistance.

\section{Conflicts of Interest}

The author declares no conflicts of interest regarding the publication of this paper.

\section{References}

(2012). Singapore Parliamentary Report (Vol. 89).

(2014). New Govt-Run Halfway House for Ex-Offenders to Be Ready by 2018. Today Online.

https://www.todayonline.com/singapore/new-govt-run-halfway-house-ex-offenders-be -ready-2018

(2018). Singapore Parliamentary Report (Vol. 94).

Abdullah, N. (2005). Exploring Constructions of the "Drug Problem" in Historical and Contemporary Singapore. New Zealand Journal of Asian Studies, 7, 40-70.

Arrêté royal réglementant les substances soporifiques et stupéfiantes, et relatif à la réduction des risques et à l'avis thérapeutique [Royal Decree regulating soporific and narcotic substances, and relating to the reduction of risks and therapeutic advice] of Dec. 31, 1930, moniteur belge[m.b.] [Official Gazette of Belgium], repealed by Arrêté royal réglementant les substances stupéfiantes, psychotropes et soporifiques [Royal Decree regulating narcotic, psychotropic and soporific substances] of Sept. 26, 2017, moniteur belge[m.b.] [Official Gazette of Belgium].

Blair, L., Sullivan, C., Latessa, E., \& Sullivan, C. J. (2015). Juvenile Drug Courts: A Process, Outcome, and Impact Evaluation. Office of Juvenile Justice and Delinquency Prevention. https://www.ojjdp.gov/pubs/248406.pdf

Central Narcotics Bureau (n.d.). Treatment and Rehabilitation Regime and Long-Term Imprisonment for Abusers of Cannabis and Cocaine.

http://www.sps.gov.sg/news-about-us/in-the-news/treatment-and-rehabilitation-regim e-and-long-term-imprisonment-for-abusers-of-cannabis-and-cocaine

Chan, K. Y. (1996). The Singapore Naltrexone Community-Based Project for Heroin Addicts Compared with Drugfree Community-Based Program: The First Cohort. Journal of Clinical Forensic Medicine, 3, 87-92. 
https://doi.org/10.1016/S1353-1131(96)90012-7

Chng, M. (2011). Modernising the Criminal Justice Framework: The Criminal Procedure Code 2010. Singapore Academy of Law Journal, 23, 23-57.

Code de la santé publique [Public health code] (Fr.).

Criminal Law (Temporary Provisions) Act (2000). Rev. Ed. Cap 67.

Criminal Procedure Code (2012). Rev. Ed. Cap 68.

European Monitoring Centre for Drugs and Drug Addiction (EMCDDA) (2015). Alternatives to Punishment for Drug-Using Offenders. http://www.emcdda.europa.eu/system/files/publications/1020/TDAU14007ENN.pdf

European Monitoring Centre for Drugs and Drug Addiction (EMCDDA) (2017). Cannabis Legislation in Europe: An Overview.

http://www.emcdda.europa.eu/system/files/publications/4135/TD0217210ENN.pdf

Executive Office of the President of the United States (2016). National Drug Control Strategy.

https://obamawhitehouse.archives.gov/sites/default/files/ondcp/policy-and-research/20 16_ndcs_final_report.pdf

Gesetz über den Verkehr mit Betäubungsmitteln (Betäubungsmittelgesetz - BtMG) [Narcotics Act], as amended (Ger.).

https://www.gesetze-im-internet.de/btmg_1981/BtMG.pdf

Giertsen, H. (2012). Policy on Drugs in Norwegian Prisons: Increased Control, Answers to Poverties and Looking for a Life after Release. Nordic Studies on Alcohol and Drugs, 29, 589-604. https://doi.org/10.2478/v10199-012-0049-0

Global Commission on Drug Policy (2016). Advancing Drug Policy Reform: A New Approach to Decriminalization.

http://www.globalcommissionondrugs.org/wp-content/uploads/2016/11/GCDP-Report -2016-ENGLISH.pdf

Intoxicating Substances Act (2001). Rev. Ed. Cap 146A.

Jalelah, A. B. (2013). Pre-Release Rehab for High-Risk Drug Offenders. The Straits Times. http://www.asiaone.com/print/News/Latest\%2BNews/Singapore/Story/A1Story201304 03-413319.html

Justis-og politidepartementet (1967). Report from the Penal Code Council. Changes in the Regulations for Violations of the Acts Related to Narcotic Drugs?

Khalip, A. (2015). EU Drug Agency Sees No U.S.-Like Cannabis Legalization Moves. Reuters. https://www.reuters.com/article/us-drugs-europe-idUSKBN0OK1U220150604

King, R. (2007). Changing Direction? State Sentencing Reforms 2004-2006. Federal Sentencing Reporter, 19, 253-260. https://doi.org/10.1525/fsr.2007.19.4.253

Krimināllikums [Criminal Law] 17.5. 1998 likums/LV, 199/200 (1260/1261)(Lat.).

Leafly (n.d.). Home Cannabis Cultivation Laws: A State-by-State Guide. https://www.leafly.com/news/cannabis-101/home-cannabis-cultivation-laws-a-state-by -state-guide

Loi du 19 février 1973 concernant la vente de substances médicamenteuses et la lutte contre la toxicomania. Mémorial $A N^{\circ} 12$ (Lux.).

Lov om gjennomforing av straff $\mathrm{mv}$. (straffegjennomforingsloven) [Act Relating to the Execution of Sentences etc. (The Execution of Sentences Act)] 18. mai $2001 \mathrm{nr} .21$ (Nor.).

Lov om legemidler m v [Act Relating to Medicinal Products] 4. desember 1992 nr. 132 (Nor.). 
Lov om straff (straffeloven) [Penal Code] 20. mai $2005 \mathrm{nr} .28$ (Nor.).

Marlowe, D. B., Hardin, C. D., \& Fox, C. L. (2016). Painting the Current Picture: A National Report on Drug Courts and Other Problem-Solving Courts in the United States. National Drug Court Institute.

http://www.ndci.org/wp-content/uploads/2016/05/Painting-the-Current-Picture-2016. pdf

Mervin Singh v. Public Prosecutor, [2013] SGCA 20 (Sing.).

Misuse of Drugs (Amendment) Act 2012, Act 30 of 2012 (Sing.).

Misuse of Drugs Act (1997). (Amendment of First Schedule) Order, GN No. S 469/1997 (Sing.).

Misuse of Drugs Act (2008). Rev. Ed. Cap 185 (Sing.).

Mitchell, O., Wilson, D. B., Eggers, A., \& MacKenzie, D. L. (2012). Assessing the Effectiveness of Drug Courts on Recidivism: A Meta-Analytic Review of Traditional and Non-Traditional Drug Courts. Journal of Criminal Justice, 40, 60-71. https://doi.org/10.1016/j.jcrimjus.2011.11.009

Nadelmann, E., \& LaSelle, L. (2017). Two Steps Forward, One Step Back: Current Harm Reduction Policy and Politics in the United States. Harm Reduction Journal, 14, 37-43. https://doi.org/10.1186/s12954-017-0157-y

Nagaenthran a/L K Dharmalingam v. Public Prosecutor, [2011] 4 SLR 1156 (Sing.).

Nesvaag, S., \& Lie, T. (2010). The Norwegian Substance Treatment Reform: Between New Public Management and Conditions for Good Practice. Nordic Studies of Alcohol and Drugs, 27, 655-666. https://doi.org/10.1177/145507251002700610

Norwegian Ministry of Health and Care Services (2009). Norwegian Drug Policy in International Fora.

https://www.regjeringen.no/globalassets/upload/hod/dokumenter-fha/san/narko-eng.p df

Osman, M. M. (2002). Drug and Alcohol Addiction in Singapore: Issues and Challenges in Control and Treatment Strategies. Journal of Social Work Practice in the Addictions, 2, 97-117. https://doi.org/10.1300/J160v02n03_07

Peh, A. L. H., \& Ng, B. Y. (2006). Medicalising the Treatment of Opioid Dependence. Annals Academy of Medicine, 35, 447-449.

Public Prosecutor v. Tan Kiam Peng, [2007] 1 SLR 522 (Sing.).

Reglamento Penitenciario (R.D. 1996, 190) (Spain).

Shanmugam, K. (2016). Singapore Statement at the UNGASS 2016 Plenary Session. https://www.mfa.gov.sg/content/mfa/overseasmission/vienna-mission/speeches_and_st atements-permanent_mission_to_the_UN/2016/201604/press_201604212.html

Singapore Corporation of Rehabilitative Enterprises (n.d.). Halfway Houses. https://www.score.gov.sg/programmes-services/community-partnerships/halfway-hous es

Singapore Prison Service (n.d.). Programmes Offered during Incarceration. http://www.sps.gov.sg/connect-us/programmes

Singapore Prison Service (n.d.). Vision, Mission \& Values. http://www.sps.gov.sg/about-us/vision-mission-values

SIRUS Norwegian Institute for Alcohol and Drug Research (2014). The Drug Situation in Norway 2014.

https://www.fhi.no/globalassets/dokumenterfiler/rapporter/2014/thedrugsituationinno rway2014.pd.pdf 
Skretting, A. (2014). Governmental Conceptions of the Drug Problem: A Review of Norwegian Government Papers 1965-2012. Nordic Studies on Alcohol and Drugs, 31, 569-584. https://doi.org/10.2478/nsad-2014-0047

$\operatorname{sr}$ (Neth.).

State Courts Singapore (2014). Community Court. https://www.statecourts.gov.sg/CriminalCase/Documents/Community\%20Court.pdf

Stevenson, B. (2011). Drug Policy, Criminal Justice and Mass Imprisonment. Global Commission on Drug Policies.

http://www.globalcommissionondrugs.org/wp-content/themes/gcdp_v1/pdf/Global_C om_Bryan_Stevenson.pdf

Straffleloven (2017). [Criminal Code] LBK No. 977 of Aug. 9, 2017 (Den.).

Substance Abuse and Mental Health Services Administration (2011). Chapter 4 Facility Characteristics and Services. https://archive.samhsa.gov/data/DASIS/2k11nssats/NSSATS2011Chp4.htm\#OTPs

Suchtmittelgesetz (1997). [smg] [Addictives Law] bundesgesetzblatt [bgbl] No. 112/1997, as amended (Austria).

https://www.ris.bka.gv.at/GeltendeFassung.wxe?Abfrage=Bundesnormen\&Gesetzesnu $\underline{\text { mmer }=10011040}$

Suventher Shanmugam v. Public Prosecutor, [2017] 2 SLR 115 (Sing.).

Tan, T. M. (2018). Law on Criminal Detention without Trial Extended. The Straits Times. https://www.straitstimes.com/singapore/law-on-criminal-detention-without-trial-exte nded

Trestní rád [Criminal Procedure Code], Zákon č. 141/1961 Sb. (Czech).

Trestní zákon [Criminal Code] Zákon č 40/2009 Sb. (Czech).

United Nations General Assembly (2015). Transforming Our World: The 2030 Agenda for Sustainable Development, Resolution 70/1.

United Nations Office on Drugs and Crime (2016). World Drug Report 2016. https://www.unodc.org/doc/wdr2016/WORLD_DRUG_REPORT_2016_web.pdf https://doi.org/10.18356/603a2a94-en

United Nations Single Convention on Narcotic Drugs of 1961 as Amended by the 1972 Protocol, 976 U.N.T.S. 14152 (1972).

United States Department of Justice (2018). Drug Courts. https://www.ncjrs.gov/pdffiles1/nij/238527.pdf

Yew, L. (1999). Effective Treatment Measures for Prisoners and Drug Addicts to Facilitate Their Reintegration into Society (pp. 301-314). UNAFEI Resource Material Series No. 54. 